\title{
Viewing Diversity in the Caribbean Diaspora: A Critical Guide to the Contemporary Film Movement
}

\section{Materre Michelle*}

The New School, New York, NY, USA

\begin{abstract}
It is an obvious statement that the people of the Caribbean diaspora are varied and abundant, and, in fact, scattered to the far reaches of the globe. It is therefore no surprise that independent media representations of this diaspora are equally as diverse and plentiful. When these independent representations (as opposed to commercially produced media) are initiated from within the community by one of the many talented, skilled and creative filmmakers actively working in the region, the results are singular and distinctive. Media makers from this region work across genres, across geographic boundaries, and for the most part, with extremely limited budgets, and still manage to produce engaging, culturally specific and relevant work that challenges mainstream media representations of people of African descent from around the globe.
\end{abstract}

\section{Keywords: Film Movement; Cultural}

\section{Introduction}

It is an obvious statement that the people of the Caribbean diaspora are varied and abundant, and, in fact, scattered to the far reaches of the globe. It is therefore no surprise those independent media representations of this diaspora are equally as diverse and plentiful. When these independent representations (as opposed to commercially produced media) are initiated from within the community by one of the many talented, skilled and creative filmmakers actively working in the region, the results are singular and distinctive. Media makers from this region work across genres, across geographic boundaries, and for the most part, with extremely limited budgets, and still manage to produce engaging, culturally specific and relevant work that challenges mainstream media representations of people of African descent from around the globe [1].

With this entry, it is author intention to discuss several contemporary cinematic representations from across the diaspora, of different genres, from the standpoint of their content, production values and relevance to the communities they represent. Author has examine the various modes and encumbrances that are presented in distributing this media, both from the traditional as well as the newer methods afforded by recent technological advances. Along the way, the piece will address the questions of how media are created when a culture is transferred to a variety of geographic locales; the effectiveness of disseminating this work to an audience that is so expansive; how the moving image contributes to our understanding of the underrepresented and misrepresented Caribbean history and culture; and how this work may help to construct a Diasporic identity among individuals across the Caribbean community.

Author connection to the Caribbean, and by extension to this work, comes through several portals - first, it is part of my ancestral heritage. Author father's family is from Louisiana, with origins from Haiti and France. Author mother's family is mostly Native American and African, being rooted in Georgia, with Cherokee blood surging throughout many generations leading up to me. It is this amazing combination of cultures and instincts that make author realize how fortunate the author is able to lay claim to such legacies of multiple warrior peoples. Secondly, author has travelled rather extensively throughout the Caribbean and has always felt at home wherever author land. Most recently, author has spent two months in Barbados as part of sabbatical from author institution where for the past eleven years author have been a professor of media studies and film. It was during author time there that author was able to really begin to understand, witness and feel real, first person connections to the people and places of the diaspora, and create the connections between the work author have been doing in media for the past almost 30 years and a wider, more global audience. In addition to teaching, author now works as a consultant to filmmakers on several topics, including and especially distribution and marketing. In addition, author has been the lead curator of the Creatively Speaking film series for the past 19 years [2]. The major objective of Creatively Speaking is to expand the exposure of independent film and video made by and about people of color to wider, more mainstream audiences. The series has been critically acclaimed, and has become a mainstay in the now global independent film community and the broader film industry.

During author sabbatical and through Creatively Speaking, author was afforded the opportunity to exhibit several films that author worked with within a context that was new to author, and to audiences that were new to this work. This was the first time many Barbadian audience goers, as well as film students at UWI were exposed to independent film made within communities of color, films that provided alternative images, histories and representations of African American and AfroCaribbean peoples across the diaspora.

Author remains a perpetual student of the globe, finding new things to learn, collaborate on, and dialogue about. Author has found that the tool of "the moving image" is a magnetic, infallible tool to bring people together from across a spectrum of backgrounds and experiences to create a forum for such dialogue. Author feels fortunate to be able to

*Corresponding author: Materre Michelle, The New School, NY, USA, Tel: 12122295155; E-mail: materrem@newschool.edu

Received June 17, 2015; Accepted November 12, 2015; Published November 22, 2015

Citation: Materre Michelle (2015) Viewing Diversity in the Caribbean Diaspora: A Critical Guide to the Contemporary Film Movement. J Mass Communicat Journalism 5: 282. doi:10.4172/2165-7912.1000282

Copyright: (c) 2015 Materre Michelle. This is an open-access article distributed under the terms of the Creative Commons Attribution License, which permits unrestricted use, distribution, and reproduction in any medium, provided the original author and source are credited. 
be part of that experience on an ongoing basis, and remain open and eager to learn from it.

The films that author have chosen to discuss are several that author have been connected to, either by having worked with the filmmakers as distribution and outreach consultant, or having exhibited the films as part of the Creatively Speaking film series. These experiences have connected author to the material in significant and complex ways which will be discussed throughout this chapter. The selections each portray distinctive representations of Caribbean peoples and their cultures, and are significant because many represent "first time" narratives represented through the moving image [3].

Author would like to begin this exploration with a quote from the film I is a Long Memoried Woman by Frances Anne Solomon. The quote comes from poet and scholar Grace Nichols, upon whose poem the film is based. At the end of this lyrical, dreamlike portrayal of the black female experience during The Middle Passage,

\section{Nichols states:}

"The legacy of slavery has given Caribbean people maybe a kind of restlessness, where part of them feel psychically connected to Africa, and maybe don't see themselves so much as rooted in the Caribbean and of belonging-that this is their country...So you have this constant movement of people. There's always this travel, even if it's happening only in the imagination, even if they don't ever go anywhere, there's always this sense of "journeying" which probably goes back to that journey from Africa." (from the documentary film I Is A Long Memoried Woman by Frances-Anne Solomon) Indeed, it can be said that Caribbean people are always journeying....across the region, across the Atlantic Ocean and Caribbean Sea, from within our hearts and minds.

We should also begin by documenting the rich historical precedent of Caribbean cinema being exhibited and written about both within and beyond the Caribbean diaspora, particularly work coming from the U.K. In 1988, an organization of scholars, filmmakers and distributors, calling themselves Celebration of Black Cinema, published a small journal BLACKFRAMES: Critical Perspectives on Black Independent Cinema in conjunction with a film series that was exhibited in New York, Boston and several locations around the globe. The founders of this series and the subsequent publication included Mbaye Cham, Pearl Bowser and Claire Andrade-Watkins. The work discussed in this journal includes those by the Black Audio Collective, the Sankofa Film/ Video Production and Ceddo Film Workshop. Each of these entities is known for producing high quality, culturally relevant independent films by filmmakers from across the Caribbean diaspora. Subsequently, in 1992, EX-ILES: Essays on Caribbean Cinema was published, edited by Mbaye Cham, highlighting work from French speaking Caribbean, Dutch speaking island nations, as well as Haiti, Jamaica and Trinidad and Tobago. Author reference these works to indicate that there is precedence for the more contemporary work we will discuss in this chapter. Referring to these works provides a basis of understanding the depth and breadth of this cinematic tradition, and allows us to pay homage to those who have led the way for the more contemporary representations. The burden of the British colonial heritage still weighs heavily on people of African descent, and, at the same time, it is the thread that connects this rich, documented past with the dynamic present. Efforts to liberate this burden are found in contemporary work that reaches into our mediated history from a place of intimacy and a perspective of community [4].

\section{Chisholm '72: Unbought and Unbossed by Shola Lynch}

The first film that author will discuss is Chisholm '72: Unbought and Unbossed. This was the first feature documentary penned by history scholar and filmmaker, Shola Lynch. Completed in 2004, immediately before the Presidential elections, the film is a historical documentary at its onset. It represents the Caribbean diaspora on several levels, and provides insights into the complex construction of the diaspora. It is a historical document, and it is also historical as a production. First, the filmmaker is of Caribbean heritage and descent, her father is Trinidadian, but she was born and raised by her Canadian mother in New York City. Shola previously worked with Ken Burns' Florentine Films on Frank Lloyd Wright and JAZZ, as well as Orlando Bagwell and ROJA Productions on EveryOther, a short in the Matters of Race series. Shola has always said that in addition to a Master 's degree in history, her most important filmmaking skill has come from competing 15 years as a winning athlete and track star-perseverance in pursuit of a goal.

The subject of the film is Shirley Chisholm, a Barbadian woman whose family immigrated to the United States before she was born, but sent her back to Barbados for her elementary schooling. Both these circumstances may seem incidental when subsumed by the story of an amazing woman who rose to power and recognition during a time in U.S. political history when women, needless to say, black women, were hardly visible, let alone considered a viable force in the patriarchal, male-dominated U.S. political landscape. And yet, Shirley Chisholm became the first black female member of the U.S. Congress by sheer determination, and an unwavering capacity for interpreting the need for justice and fairness to a constituency, primed for the ideal of creating a just and fair society. Shola successfully portrays the strength, determination and intelligence of Shirley Chisholm, who at a time when women, blacks and anyone other than white males were dominant in Washington insider politics, rarely managed to penetrate the "inner circle". Not only did Mrs. C. expose the rampant disillusion and discontent of women, young adults and all poor people - black, brown and white - she made sure this was evidenced across the globe. Shirley Chisholm was an anomaly to be reckoned with whom made certain to insert herself into the political process in a way that had never been seen prior to her entrance into the Presidential campaign of the 1970's.

In accord with the historical nature of the documentary, when presenting historical archival material, Shola chose a predominantly black and white color palette, which bursts into full Fuji chrome color, the best for portraying brown skinned subjects, when in a contemporary storytelling mode. Created with a full, rich sound design, well-planned and executed shot composition, and an editing style truly reminiscent of a passionate, eventful era gone by, the film's aesthetics alone are worthy of mention and documentation. In addition, with an original soundtrack straight out of the 70's by composer Barry Eastmond, the film takes the viewer right back to the events of the time, and a post-modern view of its politics. With the use of these techniques and finely researched and nuanced storyline, Shola presents an accurate, authentic portrait of a little known, and rarely recognized critical figure in American political history [5].

Shola wrote about the experience while still in the midst of the release in 2004 in an article for the National Urban League online magazine. She talked about what it meant to her as an African American woman of Caribbean descent to learn about Mrs. Chisholm's run for the Presidency in 1972. Shola recalls being a graduate student in American History and wondering why this part of Mrs. Chisholm's 
political career wasn't ever highlighted; we only learned about her being the "first" black woman congresswoman, and that was the extent of it.

In an article Shola wrote following the world-wind election season, she recalls what compelled her to tell Mrs. Chilsholm's story:

"Once author had an understanding of story telling, Author began to think about the politics of it. Why were some stories part of the lexicon on American history and others left out? About this time, NPR announced Shirley Chisholm's birthday. Author thought how nice, she's still alive. She's STILL alive! Author made cold calls to the offices of a number of politicians, who with? questions whether she was still alive, more times than author care to count. Black political science or Women's studies texts barely mentioned her in passing. She seemed to have been forgotten. Author became obsessed with tracking her down. In the meantime, author located her out-of-print books Unbought \& Unbossed (1970) and The Good Fight (1973), which author read with zeal. A light blub went off. Author out of hand dismissal of Mrs. Chisholm in graduate school came out of author own lack of understanding. Author had some of the "facts" but not the whole story. Author had had information without context or emotional comprehension so it hadn't mean much to me. Well, that was no longer true. The facts are that she ran for the presidential nomination and lost. The story is epic".

The significance of this production within the Caribbean community can readily be seen through the experience author had while screening the film to a predominantly Caribbean audience in Barbados as part of the film series. Audience members at The University of The West Indies at Cave Hill consisted of community leaders, students, faculty and film enthusiasts, and the response was incredulous. First of all, no one in the audience realized that Shirley Chisholm was of Barbadian descent, nor did they realize or remember the tremendous impact she had on American social and political history, for not only was she the first black Congress person, she was the first person of Caribbean descent to have created such impact upon the American political scene. It was as though my experience with this film had come full circle to be able to bring it to audiences in Barbados. It was rewarding and memorable [6].

What especially needs to be acknowledged here is that CHISHOLM '72: Unbought And Unbossed received an unprecedented distribution opportunity after its PBS broadcast in 2005. The film was acquired for DVD release by 20th Century Fox; it was the first time a major Hollywood studio picked up an independent documentary for home DVD release. This was quite a monumental accomplishment for a film of this kind, and set a precedent for others. The film was an official selection for The Sundance Film Festival where it was nominated for the Grand Jury Prize, as well as official selection at The London Film Festival, The Los Angeles Film Festival and The American Black Film Festival, and had a limited theatrical run in New York City. In addition, the film won the prestigious Peabody Award for Achievement in Journalism in April 2006. Shola also accompanied the film as a promotional tour announcing the 20th Century Fox release to more than 150 locations around the country. Again, these are examples of more history making events that occurred with the release of this essential film.

In closing, Shola recalls: "Whether you agreed with her or not, Shirley Chisholm succeeded magnificently because, while she did not win the nomination, the "Chisholm for President" campaign expanded democracy. She inspired to get politically active countless grassroots people such as Congresswoman Barbara Lee (D-CA), who at the time was a student and single-mother on public assistance. While is up to us decide if that success is enough to make the history books, in 2004 it is a crucial lesson when so many people ask: Why bother to participate at all? Chisholm's campaign trail adventures lays out the issues plainly. It is for us to grapple with them given the current state of voter participation and in light of the upcoming presidential election. It is my hope that CHISHOLM ' 72 can remind all Americans of their power while inspiring some to join the Chisholm Trail and continue fighting "The Good Fight" [1-3].

\section{The Other Side of the Water by Jeremy Robins and Magali Damas}

With the advent of this heartwarming, informative and insightful documentary, what developed was a film that epitomizes the crosscultural nature of an immigrant population; it transplants not only through its title, but also through its content. The film documents a traditional form of Haitian music called Rara that has made the journey to The Other Side of the Water (Lot bo Dlo).

The Other Side of the Water follows a group of young immigrants who take an ancient music from the hills of Haiti and reinvent it on the streets of Brooklyn. The journey of this unlikely band offers a unique insight into the Haitian-American experience, a rare glimpse into a world of music, spirituality and cultural activism. Part-carnival, part-vodoo ceremony, and grassroots protest, Rara is one of the most breathtaking and contested forms of music in the Americas. Rara originally served as a voice of the slaves in their revolt against the French, and as the voice of those struggling against ongoing dictatorships in Haiti. This documentary follows the journey of DJA RARA-the only sustained Rara band in America-through a hidden New York landscape of vodoo temples, underground economies, violent politics and ground-shaking music.

Combining archival footage and vérité narratives, this documentary focuses on the journey of the poetic visionary Pé Yves. Yves has led a Rara movement in New York for 20 years, through an era when the media accused Haitians of bringing AIDS to America, through times of civil chaos in Haiti, through police brutality riots in New York, each time re-imagining Rara as a voice for an evolving diaspora. Yet, when a new generation arrives bringing a radically different vision of the music, and the Haitian Christian community attacks Yves for promoting a Vodoo ritual, he's caught in the middle of a struggle for the meaning of Haitian identity.

Ultimately, The Other Side of the Water is about the struggle to merge the traditional and the modern, an island nation within a major U.S. city, the imagined and the real. The documentary tells the story of one man who learns to hold true to a vision, an eclectic band that comes to speak for a larger community, and a music that manages to create a new meaning of home in the diaspora [5].

The filmmakers are an unlikely and inseparable pair, Jeremy Robins and Magali Damas. Jeremy, director and co-producer, has a background as a media educator and filmmaker with a passion for visual storytelling. As a sociology and music major in college, Jeremy began making documentaries as a counselor with non-profit youth development programs, specifically youth media. An avid music aficionado, neither a Caribbean immigrant nor of Haitian descent, Jeremy was introduced to Rara by an ethnomusicologist from the

Smithsonian Folkways and was fascinated by it. Magali, coproducer, first generation Haitian American, has been involved in the film industry for fifteen years in a variety of capacities, including video production, festival organization, and media activism. As an 
Associate Producer at West Indies Productions in Haiti, Magali has helped produce and promote over forty music videos, commercials, and documentaries. She is currently the video coordinator for HaitiXchange.com.

In an interview with Haiti Xchange, here is what Jeremy had to say about how he met Magali and together produced the project: "I had been interested doing a project about Haiti for a while. Back in school author was reading C.L.R. James and Paul Farmer, and listening to Boukman and Ram. And years ago author met an old-time musicologist with Smithsonian Folkways who had traveled the world for decades recording every kind of music, and she told me that the most amazing music she's ever heard is Rara music in Haiti. Two years ago (2003), author met Magi on another project, and found out that she had been filming with a Rara band in Brooklyn for over a year. She took me to see them rehearse one night in a scrap-yard on Pacific Ave, and we haven't looked back since".

Jeremy worked on The Cause of Pierre Toussaint, a documentary on a 17th Century Haitian former slave who is now being considered for sainthood by the Catholic church. He also worked for POV/The American Documentary, editing and designing curriculum for POV's Borders (2002), a web-based documentary exploring migration and adolescent identity. So both directly and indirectly, Jeremy has been involved in revealing a Caribbean identity through his work from early on.

In 2004, Magali co-produced The Cause of Pierre Toussaint, and co-directed a music video for DJA RARA, which was featured on the national cable broadcast of Democracy Now! with Amy Goodman. From 2000 to 2002, she helped organized Haiti's second largest festival Gelee, in Les Cayes, as well as a Rara festival in Paillant. She works tirelessly to promote Haitian culture both in the U.S. and in Haiti.

When looking at both their careers side by side, it appears that both Magali and Jeremy had been embarking upon parallel paths, working towards similar goals, long before they even met. They both learned to use the power of media to influence societal issues and move audiences to take positive action. Jeremy described the journey of how the project started as ".... winding, random path, but once we started, we were propelled by the unfathomable depth of the music we were documenting, and the sense that this was a truly great story that was happening completely under the radar of America's biggest city" (from email interview with Materre) [2].

It was also a documentation of a phenomenon, because on any given Sunday summer afternoon in Prospect Park Brooklyn, between 4,000 -8,000 Rara fans can be seen following DJA RARA on its musical journey through the streets of Brooklyn. Where else could that have happened except in a transplanted Caribbean culture? Author asked Jeremy about his cultural philosophy on the Caribbean diaspora:

"Author thinks the Caribbean in general is one of the most swirling, complexes, nuanced and culturally overlooked parts of the world. Just looking at the layers of history and symbolism of something as seemingly straightforward as Carnival is mind-blowing. On top of it are the long-entrenched Chinese, Indian and Jewish footholds in much of the Caribbean, which further inform and complicate the cultures. What's most compelling to me from the scholarship I've read is how all of this complexity gets played out most dynamically in a the languages of 'attitude,' 'posture,' 'gesture,' and of course music - creating nonverbal discourses that often get dismissed as being meaningless or superficial. Author find it fascinating to look at these things as a sort of philosophy in themselves: through the nuances of these gestures and styles, really vital aspects of identity and community are worked out."
The impact the film has had on the community it documents is still immeasurable, as there has been so much negative mediated exposure about Haiti and its people that this documentary is like a breath of fresh air. Here, we have a group of young Haitian men, now living outside their homeland, successfully extending the traditions of their culture through indigenous music, across the diaspora, outside of its geographic boundaries. The continued impact of this film is represented through the fact that it is still being shown at events, conferences, classrooms and museums around New York City and across the country.

Magali and Jeremy have both endeavored to offer imagery that counters the "doom and gloom" aspect of what most mainstream media purports Haiti to be. With The Other Side of the Water, they have in fact accomplished this quite successfully and fully. The wider Caribbean and African American communities in New York have embraced this film because of its positive message, and, as Magali says, feel gratified and enlightened to see a: "nuanced, non-sensationalized story about Haiti, and one that wasn't just about military coups or natural disasters. There's always something powerful about simply hearing your story being told, and hearing your experience validated and reflected in the mainstream. Unfortunately, that's happened far too infrequently for many of us Haitian-Americans. Author wanted to tell stories about my culture since it was always shown in a negative light, especially in relation to the Rara. Author have never really seen any images, positive or negative, about Haiti as a child when I was growing up."

When author asked Magali what the overall experience was like for her, she recalls: "It was a great experience to create The Other Side of the Water. Author learned a lot about a part of his culture which author really didn't know...plus it gave me a chance to meet people author would not have interacted with due to our different class positions...”.

Class, yet another aspect of the Caribbean culture that transplanted to the United States, perhaps reluctantly, still remains intact. Author contends that it is through the power of the moving image that these institutional impositions against non-mainstream cultures can be deconstructed and dissolved. Once acknowledged as a societal construct, we can hopefully see beyond and move away from these limitations purposely imposed as a means of continued repression.

Author have had the pleasure and honor of working with the filmmakers for more than 5 years now, consulting on their marketing, distribution and educational outreach plans to bring the film to the broadest audience possible. Author first introduced the film to the National Black Programming Consortium that led to the broadcast of The Other Side of the Water on PBS World's AfroPop series (January 2011). We also featured the film at a Creatively Speaking program at BAMcinématek in Brooklyn (September 2009) which led to the film garnering considerable press attention as part of West Indian Labor Day weekend festivities. The weekend concluded with a live concert with DJA RARA, the band featured in the film $[3,4]$.

\section{Nurse Fighter Boy by Charles Officer}

Talking about this film is truly an emotional experience for me. It is a poetic, universal love story with vibrant, authentic cultural references and significance. It is visually stunning with fully developed, complex, black characters rarely evidenced on the big screen. It is a lost gem of a film. Yes, lost, because unfortunately, this film never received a theatrical release, even after screening in the prestigious Canadian Front series at the Museum of Modern Art in New York City in 2009. It is a film made on an extremely low budget and yet has received considerable recognition from many major film festivals, including 
Toronto, Seattle, Warsaw, Edmonton and the European Film Market. However, when larger independent distributors consider "picking up" the film for distribution, they got cold feet, feeling it was too "risky" a venture-risky because they didn't see the potential audience for this film beyond the typical "art house" market. Most mainstream distribution outlets don't understand that what they probably would consider a "niche" market is actually a major market, particularly in reference to the Caribbean audience in North America which stands at approximately 22 million people.

Charles' career began studying visual art at Cambridge University and working as a graphic designer. He then became an actor, attending classes at The Neighborhood Playhouse in New York City, and performing in numerous stage, film and television productions. His debut short, When Morning Comes premiered at the 2000 Toronto International Film Festival (TIFF) to wide acclaim, and then, in 2001, upon completion of the Directors Lab at the Canadian Film Centre, Charles premiered his second film, Short Hymn_Silent War at TIFF 2002, where the film received a Special Jury Citation for Best Canadian Short. In 2007, the $57^{\text {th }}$ Berlinale Film Festival selected NURSE. FIGHTER.BOY to participate in the Sparkling Tales Writer's lab, and the rest is history. Currently, Charles is developing a documentary on Harry Jerome, in collaboration with the National Film Board of Canada. NURSE.FIGHTER.BOY is Officer's first feature length film.

While doing research to see what others have written about this film, it became evident that author needed to write something about it on my own, as none of the descriptions, not even the one rendered by the film's distributor, do it any justice [5].

NURSE. FIGHTER. BOY. is the story of a mother and son; it is the story of the economic reality that bonds a caring community; and above all, it is a love story. It is also about the resilience and determination of black women, and the sacrifices and compromises we make for the benefit of our children. It is an emotional rollercoaster, with performances that make you feel like you want to know these characters as real people, up close and personal. You will want to take the boy Ciel home with you, and you will want to fall in love, the deep, spontaneous, reckless kind of love that you will probably only experience once in a lifetime.

Not one of the reviews, with an exception of the Toronto Film Festival blog, talks about these aspects of the film. This lack of understanding and depth of conscious regretfully compromises the audiences for which the work is intended to be seen, that is, people of color living in urban, sometimes impersonal environments.

We need to write our own reviews, make our own assessments, become our own cultural ambassadors to reach more mainstream readers/viewers so that they can gain a deeper, more nuanced understanding of our world.

Aesthetically, the film is stunning. The opening scene is a menagerie of colors and light, enticing music, slight of hand movement and a suspension of reality. Your senses are overloaded with sights, sounds (thanks to an amazing soundtrack by John Weisman) and this enchanting kid named Ciel (played by Daniel Gordon) doing magic tricks. The audience is treated to an intimate glimpse into the lives of a mother and son and their extraordinary relationship.

Charles Officer's film begins with his own personal story. Raised by a family of women, Charles recalls his sister's experiences with men, with health issues, with being black women in a society that rarely lifts up women of color in a positive, endearing way. Charles more than makes up for that with his recollections through this film. When asked about his background, Charles cites several backgrounds and cultures - Chinese, Jamaican, British - with lives in New York, the U.K., Toronto and Jamaica among others. Author journey through these existences led him to the stories that author wants to tell that are truly representative of a diasporic experience. Author feels that artists often get distracted by their journeys by trying more commercial routes; however, author feels that we are doing ourselves a disservice if we lose sight of these inherent values instilled from within families, where values and traditions are deeply rooted. It is these values that connected the film to the Toronto Caribbean community, who responded to the film with overwhelming support.

In a Director's Statement that appears on the inside cover of the DVD released by Film Movement, the film's U.S. Distributor, Charles Officer says:

"Author mom was a nurse and the black men in author world were all deemed as fighters...So author thought of this detached man, who is finally affected by love...People describe love in all kinds of ways, but author think the involuntary part of love is magical. with cinema, especially black cinema, Author hardly see any magic. So author really wanted to create a character that kind of resembled me...when author was young, Author was interested in magic; Author always wanted a tough guy to be author dad, author wanted a superhero to look after author mom. Author sister has Sickle Cell Anemia. She was told she would not live past thirty. That kind of information can have a very bizarre effect on your psyche. So, when she was edging up to her 30th birthday, she decided she wanted to have a child. Everyone thought she was crazy, that she was putting her life in jeopardy. Author really stuck by her...she didn't actually expect to survive it. Author understood she wanted to leave a part of herself behind. She did survive -- then she had to learn how to look after her son. Author want to show people of a different cultural background in Toronto, Canada, the place where author was born... author want to make a hopeful, but real film that deals with death and humanity. Author wants to humanize some black people. That's what author really want to do -- it's my mission. Author hope that this is the first step in doing that. The impact on the community can be seen through several lenses. First, the film was released in Toronto on the anniversary of Bob Marley's birthday in 2009, and managed to maintain enough box office to remain for five weeks in the theatre, even when the distributor only paid for two weeks of print advertisements. What a testimony to the "word of mouth" tradition that remains an integral part of this community and created a success for the film and the filmmaker. Even when the Canadian distributor neglected to maintain the momentum for the film through online, "nocost" resources, the film and filmmaker had accumulated a significant fan base that helped to export the Caribbean cultural experience to a larger audience. On the other hand, European support for the film has been incredible. It received an audience award at the MannheimHeidelberg International Film Festival, and was bought by several European entities at the European Film Market. However, in the end, it was primarily because the filmmaker showed his loyalties and support and took the film to the community, that the community, as Charles says, "gave it back." When asked if he would like to see the film reach a larger diasporic community, Charles responded that he would indeed like to see international broadcast opportunities as well as more U.S. theatrical exposure. For indeed, if the film reached such a critical mass audience in Toronto on such limited resources, there could be many more, well-developed opportunities with a bit of strategic planning and execution. Hoping to assist Charles in this endeavor is CaribbeanTales Worldwide Distribution, the first Caribbean focused film Distribution 
Company to exist in the world, working in collaboration with New York based Autonomous Entertainment, Inc. We will talk about these two entities later in the chapter.

Not only did Charles successfully fulfill his mission, he did it with grace, sophistication and authenticity. Because we so rarely see black people experiencing everyday, normal, "human" experiences on the big screen, this film makes us even more encouraged that it is possible to do AND to find an audience for it.

When asked if he felt his film interprets a "Caribbean identity", Charles really couldn't pinpoint a separation between his influences and his own reality and background - which is varied and fluid and the larger concept of a Caribbean identity, mostly because the latter is so flexible and diverse. His intention was to create a story that was culturally nuanced, but that would be easily accessible to a non-Caribbean audience. It is indeed a small story with monumental implications, successfully drawing from the variances and vagaries that make up the restlessness and diversity that IS the Caribbean experience [7].

\section{Kingston Paradise by Mary Wells}

Author was anxious and excited to see a small clip of this film at the first installment of the CaribbeanTales Film Festival in Barbados in February 2010. The first narrative feature film by this filmmaker was shot entirely on location in a violent-torn Jamaica, when drug lord legend and kingpin, Christopher "Dudus" Coke was still on the run, and holding entire neighborhoods hostage within the confines of the bustling, metropolitan, international city of Kingston. The clips were screened during a "pitching session." The film is all that you expect it to be, definitely different from its male counterparts' similar work. It is compelling, beautiful to look at, culturally specific, funny, charismatic and touching, with realistic portrayals of real women, not video vixens.

More deeply rooted and nuanced, one finds the storyline to have elements of both the mundane and the profound, as based upon a description written by the filmmaker: "The storyline depicts a desperate, chaotic and violent inner-city Kingston where there are few choices for the youth. Small time hustler, Rocksy, (a taxi driver/part-time pimp), with his prostitute 'friend' Rosie, dream of something different-a real life, a future. Rosie's dream is to become "someone", like a nurse. Rocksy, at first, only sees the immediate-the need to make money by any means necessary. In his mind, author is only temporarily in his present abode-a rented room within a dilapidated tenement, but he too has a dream of owning a small business. On the peeling wall, Rosie prominently places a painting she owns that gives them both hope, and something tangible to cling to-an exotic beach view of another, more peaceful, world-a world ironically only minutes away, yet they exist miles and worlds apart. In the midst of his frustration, poverty and pain, something changes within Rocksy. something rises and like the sun, it sets. In the context and contrasts of the Jamaican landscape, its backstory is political, as the current embedded system doesn't adapt easily to change" (Wells, Synopsis n.d.).

The filmmaker is Mary Wells, Jamaican born, but a naturalized U.S. citizen, who has lived in Jamaica, the U.S. and the U.K., and feels that her parents were the most direct influence on her becoming a filmmaker, as they enthusiastically encouraged her artistic pursuits. Her mother is a well-known Jamaican visual artist, Dorothy Enriques Wells, and her father, now deceased, was a well-known veterinary surgeon, who did a lot of international diplomatic work in Haiti and the English speaking Caribbean.
Growing up within a small island society creates a strong sense of selfworth and determination, but also imposes an anxiety, a need to gain access to the larger, more global society outside the reach of the confines of what must feel like a "small stage." While the world looks to Jamaica for its music and culture, it has also helped to expand the desire for broader reach across the tropical shores, and so Wells left the Caribbean to study abroad in the USA and to travel the world. Being exposed to media at an early age, she picked up a camera at age ten. Once she left Jamaica, she felt the need to express and explore her "third world" identity, and to offer to others an interpretation of the space and place from whence she came. Thus, she started creating media to break the stereotypes and "create the non-mainstream... for the mainstream! "As for the question of "identity", Wells says her film "is like a mirror... a view of who we are - the good, the bad and the ugly. I didn't want characters to speak 'English'... they expressed themselves in full Jamaican patois."

Spoken entirely in Jamaican patois, you may be able to determine some of the dialogue, but a full subtitled version is underway for those of us not as knowledgeable. What you will find immediately upon first glance is an authentic, truthful insider's perspective, not an "outsider's" ethnographic gaze. This is the image most widely seen and depicted by mainstream media: A Jamaican population inundated by U.S. and European film crews, exploiting the beautiful island for its lush locales and pulsating Reggae rhythms. So in essence, yes, the film is a full representation of one of many Caribbean identities, which Wells hopes translates well to the screen. Because her film is still in the postproduction stages as author write this, the question of community impact can't be answered at this moment. Yet, just the mere fact that the film was produced inside the community, by the community, is a testament to how different this experience is, and represents the possibilities of expanding audiences and outlets for well-produced, high quality, universally conceived stories, from independent filmmakers whose voices have yet to be heard across the larger world stage. The film has since been released to modest success on the festival circuit and is, as of this month, June 2015, being screened for the first time in Jamaica. The film is currently in DVD distribution through California Pictures in Los Angeles.

\section{Frances Anne Solomon-caribbean tales worldwide distribution and Caribbean tales film festival}

One of the most energetic, committed and determined women in the field of Caribbean media that author have met to date is Frances Anne Solomon. This is a woman who does not know the words "can't" or "no;" she is tireless in her commitment to bringing positive images of Caribbean people to the big screen, both through her career as an independent filmmaker, as well as her more recent role as film distributor. Solomon launched CaribbeanTales Worldwide Distribution, the first film and television Distribution Company focused on increasing the exposure of media by and about the Caribbean people. She is at the helm as CEO and director of CTWD. Her first film, I Is A Long Memoried Woman, is a personal memoir in a way. While at first glimpse it tells the story of "the middle passage" from the perspective of the African woman, it does so through Gayle Nichols' captivating poem. It also does so with a cast from every color spectrum and from every end of the globe, much like the composition of Solomon's own unique heritage. What My Mother Told Me, Frances Anne's second film, tells the story of a woman returning from life in the U.K. to live in Trinidad, much like the filmmaker's own experience. Solomon has gone on to make more than fifteen films, many of which are award 
winners, and yet, until now, few have received the recognition and exposure they truly deserve.

From her filmmaking experience, Solomon quickly learned that there is another critical part of the process, and that is getting her films out into the marketplace. After having difficulty with accessing that market place with her own work, she started her own film festival CaribbeanTales - now in its eighth year [7].

She inherited a strong sense of self from a family background where her grandfather, father and uncles were the "fathers of liberation" for the island nation of Trinidad. Central to the development of the independence of their nation, they were diplomats who traveled all over the world. Solomon admits to having had no real one "place" to call her own, but was really a child of the world in many ways. This is actually an amazing example of what the Caribbean diaspora looks like today: It is everywhere and everywhere is in them. The "world view" perspective that she and her brother had as children was unique to them then, but now, it is a matter of course that Caribbean people are "people of the world." She sees herself through the eyes of her family, an upper middle class, educated and politically active and engaged set of expectations. Seeing how black people lived in other places in the world, especially in the U.K., with such a limited scope, and with few options, she became disillusioned and ambivalent. She also grew up without her mother, which made her very independent from a very early age. When she was able to move away from the Caribbean and make a way for herself, she took advantage of it and moved to Toronto, Canada as a teenager. It has made her a "product of the Caribbean," yet at the same time "a citizen of the world."

Her political philosophy and cultural references are very much tied to her upbringing and parental experiences from both her mother's and father's sides of the family. She and her family lived in New York, the U.K., Canada, and usually she was the only "black" kid in most of the schools she attended. Returning to Trinidad, she was recognized as the granddaughter of one of the "fathers of the nation," and so was considered part of the "black ruling class". They saw her family as being the "saviours" of Trinidadian society. That was indeed a "burden" in a way, as she realized from an early age, as she was expected to live up to the expectations of her family and their society. Therefore, her identity was formed by all these experiences while still being central to the Caribbean. Living in England, it was forced on her that she was "black", as she had never thought about color in that way before. It wasn't something that was present in her everyday life. But now, in England, as in the United States, you had to be "marked", "categorized;" you had to take sides.

The impact on the community can be seen through Solomon's creation of the CaribbeanTales Film Festival. The festival highlights the work of film and video makers from across the Caribbean diaspora, and locates in two places - Toronto and, for the last 5 years, Barbados. While still recognizing the need for showcasing work, the work also had to become a business, making money and increasing exposure to audiences across the globe. Thus, emerged CaribbeanTales Worldwide Distribution, a full service distribution and marketing entity focusing on work made by and about Caribbean people across the diaspora. Other principals include creative industries specialist Dr Keith Nurse, economist and businessman, Dr Terrence Farrell, and media personality and producer, Lisa Wickham.

Formed in May 2010, CaribbeanTales Worldwide Distribution (CTWD) is the first ever film distribution company of its kind in the English-speaking Caribbean. Launched regionally in Barbados with the mission of "Taking Caribbean Films to the World," the company aims to become known for its high quality, professionally developed content, poised for penetrating an international marketplace. For Caribbean filmmakers, CTWD will provide a long sought after support for their work, seeking outlets beyond the region. CTWD will actively engage in relationships with international buyers and broadcasters looking for quality Caribbean-themed content. Caribbean Tales Worldwide Distribution is a full service marketing and distribution company that acquires exclusive, long-term rights to Caribbean-themed content for television, educational, home entertainment and Internet distribution. The company holds marketing events through the Caribbean Tales Film Festival Group, and provides co-production services to producers.

One of the unique services provided by CTWD is the Content Incubator, a series of professional development workshops for specially selected filmmakers from across the region. The first Content Incubator was held in Toronto, Ontario in September 2010, right before the Toronto International Film Festival, and was a huge success. Twenty-five filmmakers were in attendance for the first session led by CTWD principals Dr Keith Nurse, Frances-Anne Solomon and Lisa Wickham, and myself as Autonomous Entertainment head. A second Content Incubator was held in March 2011 as part of the $2^{\text {nd }}$ annual CaribbeanTales Film Festival in Barbados, West Indies. Here, we worked with ten filmmakers from across the Caribbean diaspora, Canada, Trinidad/Tobago, Martinique, Dominica, Jamaica and Barbados. In addition, international industry professionals attended the last day of the festival and formed a panel of jurors, listening to, offering advice for and critiquing the project pitches of the ten filmmakers we had been working with all week.

Industry guests as part of the second Incubator series included Sonja Heinen, World Cinema Fund and Berlinale Co-Production Market; Gabriela Moennig, Caribbean-German TV; Anita Bully, Dominca Film Commission; Matthijs Wouter Knol, Berlinale Talen Campus, Programme Manager; Agnieszka Moody, Director, Media Desk/ UK; Tony Coco-Viloin, Regional Counsel for Culture and The Arts, Guadeloupe; Lars Soderstrom, Caribbean Broadcasting Corporation; and Camille Selvon Abrahams, Creative Director, Full Circle Animation Studies, Trinidad and Tobago. To date, the distribution program has acquired a catalogue of over 80 films and television programs by some of the best filmmakers from the Caribbean and the Diaspora with the assistance of Autonomous Entertainment (AEi) [7].

\section{Remixed and remastered: Defining and distributing the black image in an era of globalization (R2)}

In April 2011, another distribution milestone has been met. As conference chair, with a team consisting of New School faculty, staff, student and alumni, an immensely successfully first edition of a unique conference entitled Re-Mixed And Re-Mastered: Defining And Distributing The Black Image In An Era Of Globalization (R2) was held at The New School University in New York City. The two-day conference was attended by more than 200 media makers, industry professionals, students, film scholars and critics.

The main objective of the conference was to create a forum where filmmakers, industry professionals, academics, critics, scholars and students could interact, network and exchange ideas and information. The ultimate outcome would be for the resources of individuals and institutions within that room to come together and create our own distribution networks where we are no longer beholden to the Hollywood models, misrepresentations, lack of cultural understanding; and marketing conformations that do not take our audiences into 
consideration. To that objective, we had more than 20 independent filmmakers in attendance. Author opened the conference on Friday night with a resounding "call to action" by keynote speaker Jill Nelson, followed by a screening of the then recently released film I Will Follow by Ava DuVernay. Ava had just completed a three-week theatrical run with her first feature film, utilizing a new model for distribution and promotion with the acronym AFFRM, the African American Film Festival Releasing Movement. The idea behind AFFRM is to utilize the Black content film festivals across the country as the promotional outreach connectors to audiences in key markets across the country. Initially beginning in five markets (New York, Los Angeles, Seattle, Philadelphia and Atlanta), the film quickly gained momentum and expanded to 21 markets across the country in 3 weeks!

Elaborating upon the design of AFFRM, the idea is one that makes use of the networks that already exist throughout the film festival circuit the U.S. that focuses on work by people of African descent - African Americans, Caribbean Americans and Africans. The festivals provide their social media outlets and contacts and share in the box office in return. This is exactly what we had in mind in the development of R2, which we plan to revisit on a bi-annual basis, with frequent, ongoing contact to those who attended the first conference [6].

\section{Conclusions}

From the above study we can conclude that the weekend with a sense of what was possible, and an affirmation that we do have the tools, resources and knowledge within our own communities to create an impact on image creation in this society, and across the globe. The work of Caribbean media makers is a major part of the content that has broadbased appeal, but to date has had little opportunity to be recognized outside of the region. With the initiatives in place such as CaribbeanTales Worldwide Distribution, Re-Mixed and Re-Mastered
(R2), and the recognition of Caribbean made work in industry established settings such as the Trinidad and Tobago Film Festival, Toronto Film Festival, Tribeca Film Festival, Pan-African Film Festival and new models for distribution such as AFFRM and OneCaribbean Television, the immediate future is bright and hopeful. As we all know, it will take continued hard work and a sustained momentum to make it possible, but through true collaboration, mentoring and networking, author was more than convinced that it's possible and probable that we will see a major shift in Hollywood perspectives within the next three to 5 years-away from formulaic cinematic endeavors, European based character driven, high priced with low returns-to a more truly diverse, truly universal representation of people of color from across a diaspora that includes the Caribbean, Africa, Latin America and the U.S. This essay has simply been an effort to document a small sampling of the work that has happened to date, so that we can see our progress in timeless print, as well as in a virtual space and time. Author was proud, privileged, and committed to being an integral part of these efforts, and determined to make this goal a reality.

\section{References}

1. DuVernay A (2010) I Will Follow. Los Angeles, CA.

2. Wells M (2004) Kingston Paradise. Toronto, Canada, National Urban League Newsletter.

3. Materre M (2004) On the Chisolm Trail - CHISOLM ' 72 Unbought and Unbossed at the DNC.

4. (2010) The Other Side of the Water. Press Kit.

5. Charles Officer (2008) Nurse Fighter Boy. Metuchen, NJ, Passion River

6. Robins J, Damas M (2010) The Other Side of the Water. Toronto, Canada: Caribbean Tales Worldwide Distribution.

7. Solomon FA (1995) What My Mother Told Me. Toronto, Canada, Caribbean Tales Worldwide Distribution. 